\title{
SISTEM PAKAR UNTUK MENDIAGNOSA PENYAKIT PNEUMONIA MENGGUNAKAN METODE CERTAINTY FACTOR DAN FUZZY LOGIC TSUKAMOTO BERBASIS WEB
}

\author{
Temayori Arni Chasshidi' ${ }^{1,}$ Muhammad Reza Putra ${ }^{2}$ \\ Universitas Putra YPTK Padang, Indonesia \\ email: temayorichasshidi@gmail.com, muhammad_reza@upiyptk.ac.id
}

\begin{abstract}
Abstrak
Paru-paru merupakan salah satu organ vital pada tubuh manusia. Memiliki fungsi utama sebagai alat pernafasan manusia dengan memasukkan oksigen dari udara luar melalui mulut dan hidung ke dalam aliran darah dan didistribusikan ke seluruh bagian sel, ketika sel bekerja maka akan menghasilkan gas buangan berupa karbondioksida. Pneumonia atau yang biasa disebut dengan paru-paru basah ini merupakan infeksi yang menyerang jaringan paru-paru. Pneumonia bisa disebabkan oleh infeksi bakteri, virus, ataupun jamur. Dikarenakan gejala penyakit pneumonia ini mirip dengan gejala flu, maka banyak orang yang seringkali terlambat menyadari atau bahkan membiarkannya saja. Metode Certainty Factor dan Fuzzy Logic Tsukamoto memiliki kecocokan dengan permasalahan yang ada pada penyakit Pneumonia, dimana penyakit Pneumonia ini sulit dikenali oleh masyarakat karena mirip dengan gejala infeksi saluran pernapasan lainnya, seperti flu dan bronkitis. Metode Certainty Factor dan Fuzzy Logic Tsukamoto ini sangat cocok digunakan untuk sistem pakar yang mendiagnosa suatu penyakit yang belum pasti.
\end{abstract}

Keywords: Paru-paru, Pneumonia, Sistem Pakar, Certainty Factor, Fuzzy Logic Tsukamoto, Berbasis Web

\section{PENDAHULUAN}

Pneumonia atau yang biasa disebut dengan paru-paru basah merupakan infeksi yang menyerang jaringan paruparu. Pneumonia adalah penyakit infeksi akut yang mengenai parenkim paru, distal dari bronkiolus terminalis yang mencakup bronkiolus respiratorius dan alveoli, serta menimbulkan konsolidasi jaringan paru dan gangguan pertukaran gas setempat. Pengidap pneumonia biasanya akan mengalami gejala berupa sesak napas, batuk berdahak, demam, serta menggigil. karena gejala penyakit pneumonia ini mirip dengan gejala flu, maka banyak orang yang seringkali terlambat menyadari atau bahkan membiarkannya saja.

Certainty Factor adalah suatu metode untuk membuktikan apakah suatu fakta itu pasti ataukah tidak pasti yang berbentuk metrik yang biasanya digunakan dalam sistem pakar. Sedangkan, metode Fuzzy Tsukamoto adalah salah satu metode fuzzy logic yang memiliki toleransi pada data yang ada dan sangat fleksibel. Metode ini juga cepat dalam melakukan komputasi dan lebih intuitif. Terlihat kecocokan antara metode Certainty Factor dan Fuzzy Logic Tsukamoto dengan permasalahan yang ada pada penyakit Pneumonia, dimana penyakit Pneumonia ini sulit dikenali oleh masyarakat karena mirip dengan gejala infeksi saluran pernapasan lainnya, seperti flu dan bronkitis. Metode Certainty Factor dan Fuzzy Logic Tsukamoto ini sangat cocok digunakan untuk sistem pakar yang mendiagnosa suatu penyakit yang belum pasti.

\section{METODE PENELITIAN}

Agar penelitian dapat terarah dan tujuan tercapai, maka penulis membentuk kerangka penelitan guna memperjelas urutan kegiatan yang dilakukan, sebagai berikut: 


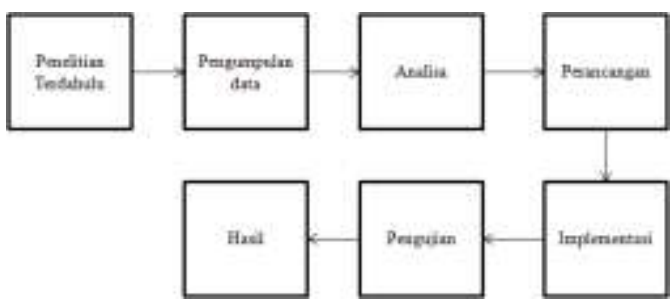

Gambar 1. Kerangka penelitian

Penelitian dilakukan dengan mencari suatu masalah, lalu mengumpulkan data dari seorang pakar yang merupakan dokter spesialis paru. Setelah data didapatkan, selanjutnya data akan dianalisa, dan dibuat perancangan untuk pembangunan aplikasi. Selanjutnya diimplementasikan dan diuji hingga menciptakan suatu hasil.

\section{HASIL DAN PEMBAHASAN}

\subsection{Analisa}

Jumlah penyakit dalam sistem pakar mendiagnosa penyakit Pneumonia adalah 2 macam tingkatan:

Tabel 1. Penyakit pneumonia

\begin{tabular}{|c|c|}
\hline $\begin{array}{c}\text { Kode } \\
\text { Penyakit }\end{array}$ & Nama Penyakit \\
\hline P1 & Pneumonia Rendah \\
\hline P2 & Pneumonia Berat \\
\hline
\end{tabular}

Sumber :Dokter Spesialis

Tabel 2. Himpunan fuzzy

\begin{tabular}{|l|l|l|r|}
\hline No & Variabel & $\begin{array}{l}\text { Himpun } \\
\text { an fuzzy }\end{array}$ & Domain \\
\hline 1 & \multirow{2}{*}{$\begin{array}{l}\text { Suhu badan } \\
\text { (G1) }\end{array}$} & Rendah & {$[35-36.5]$} \\
\cline { 3 - 4 } & & Normal & $\begin{array}{r}{[36.5-} \\
38]\end{array}$ \\
\cline { 3 - 4 } & & Tinggi & {$[38-39]$} \\
\hline 2 & Leukopenia & Rendah & {$[4500-$} \\
& $(G 2)$ & & $5000]$ \\
\cline { 3 - 4 } & & Normal & {$[5000-$} \\
& & & $9500]$ \\
\cline { 3 - 4 } & & Tinggi & {$[9500-$} \\
& & & $10000]$ \\
\hline 3 & Frekuensi & Normal & {$[13-20]$} \\
\hline
\end{tabular}

LPPM Universitas Putra Indonesia YPTK Padang

\begin{tabular}{|l|l|l|r|}
\hline & $\begin{array}{l}\text { pernafasan } \\
(\mathrm{G} 3)\end{array}$ & Cepat & {$[20-29]$} \\
\hline 4 & $\begin{array}{l}\mathrm{PaO}_{2} / \mathrm{fiO}_{2} \\
(\mathrm{G} 4)\end{array}$ & Rendah & {$[250-$} \\
& & Normal & {$[300]$} \\
\cline { 3 - 4 } & & Normal & {$[7-20]$} \\
\hline 5 & $\begin{array}{l}\text { Uremia } \\
(\mathrm{G} 5)\end{array}$ & Tinggi & {$[20-29]$} \\
\hline 6 & $\begin{array}{l}\text { Trombosit } \\
(\mathrm{G} 6)\end{array}$ & Rendah & {$[100.000$} \\
& & & - \\
& & Normal & {$[200.000]$} \\
\cline { 3 - 4 } & & & - \\
& & & $400.000]$ \\
\hline
\end{tabular}

Tabel 3. Himpunan non fuzzy

\begin{tabular}{|c|c|c|c|}
\hline $\begin{array}{l}\mathrm{N} \\
\mathrm{O}\end{array}$ & Variabel & $\begin{array}{l}\text { Non } \\
\text { Fuzzy }\end{array}$ & $\begin{array}{c}\text { Domai } \\
n\end{array}$ \\
\hline \multirow[t]{2}{*}{1} & \multirow[t]{2}{*}{ Batuk } & $\mathrm{Ya}$ & [0-1] \\
\hline & & Tidak & [0-1] \\
\hline \multirow[t]{2}{*}{2} & \multirow{2}{*}{$\begin{array}{l}\text { Terdapat } \\
\text { infiltrate/air } \\
\text { bronchogram }\end{array}$} & $\mathrm{Ya}$ & [0-1] \\
\hline & & Tidak & [0-1] \\
\hline \multirow[t]{2}{*}{3} & \multirow{2}{*}{$\begin{array}{l}\text { Perubahan } \\
\text { karakteristik } \\
\text { sputum/purulen }\end{array}$} & Ya & {$[0-1]$} \\
\hline & & Tidak & {$[0-1]$} \\
\hline \multirow[t]{2}{*}{4} & \multirow{2}{*}{ Nyeri dada } & $\mathrm{Ya}$ & {$[0-1]$} \\
\hline & & Tidak & [0-1] \\
\hline \multirow[t]{2}{*}{5} & \multirow[t]{2}{*}{ Sesak } & $\mathrm{Ya}$ & [0-1] \\
\hline & & Tidak & [0-1] \\
\hline \multirow[t]{2}{*}{6} & \multirow{2}{*}{$\begin{array}{l}\text { Memiliki tanda- } \\
\text { tanda } \\
\text { konsolidasi, } \\
\text { suara napas } \\
\text { bronchial dan } \\
\text { ronki }\end{array}$} & $\mathrm{Ya}$ & [0-1] \\
\hline & & Tidak & [0-1] \\
\hline \multirow[t]{2}{*}{7} & \multirow{2}{*}{$\begin{array}{l}\text { Terdapat } \\
\text { infiltrat } \\
\text { multilobus }\end{array}$} & $\mathrm{Ya}$ & [0-1] \\
\hline & & Tidak & [0-1] \\
\hline \multirow[t]{2}{*}{8} & \multirow{2}{*}{$\begin{array}{l}\text { Kesadaran } \\
\text { menurun/disori } \\
\text { entasi }\end{array}$} & $\mathrm{Ya}$ & [0-1] \\
\hline & & Tidak & [0-1] \\
\hline \multirow[t]{2}{*}{9} & \multirow{2}{*}{$\begin{array}{l}\text { Hipotensi yang } \\
\text { memerlukan } \\
\text { resusitasi cairan } \\
\text { agresif }\end{array}$} & $\mathrm{Ya}$ & [0-1] \\
\hline & & Tidak & [0-1] \\
\hline
\end{tabular}




\begin{tabular}{|c|l|l|l|}
\hline 10 & $\begin{array}{l}\text { Memiliki } \\
\text { riwayat } \\
\text { penyakit paru } \\
\text { lainnya }\end{array}$ & Ya & {$[0-1]$} \\
\cline { 2 - 4 } & Tidak & {$[0-1]$} \\
\hline
\end{tabular}

Tabel 4. Keyakinan himpunan non fuzzy

\begin{tabular}{|l|c|}
\hline $\begin{array}{c}\text { Himpunan non } \\
\text { fuzzy }\end{array}$ & $\begin{array}{c}\text { Drajat } \\
\text { Keanggotaan }\end{array}$ \\
\hline Sangat Yakin & 1 \\
\hline Yakin & 0.8 \\
\hline Cukup Yakin & 0.4 \\
\hline Tidak Yakin & 0.2 \\
\hline
\end{tabular}

\section{Fuzzyfikasi}

Suhu Badan

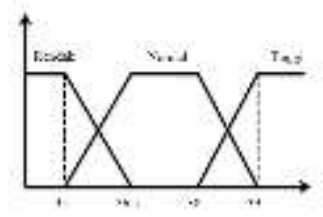

Gambar 2. kurva variabel suhu badan

$$
\begin{aligned}
& \mu[\text { Suhu Rendah }]= \begin{cases}1 & ; x \leq 35 \\
\frac{36.5-x}{36.5-35} & ; 35 \leq x \leq 36.5 \\
0 & ; x \geq 36.5\end{cases} \\
& \mu[\text { Suhu Normal }]= \begin{cases}0 & ; x \leq 35 \\
\frac{x-35}{36.5-35} & ; 35 \leq x \leq 36.5 \\
1 & ; 36.5 \leq x \leq 38 \\
\frac{39-x}{39-38} & ; 38 \leq x \leq 39 \\
0 & ; x \geq 39\end{cases} \\
& \mu[\text { Suhu Tinggi }]= \begin{cases}0 & ; x \leq 38 \\
\frac{x-38}{39-38} & ; 38 \leq x \leq 39 \\
1 & ; x \geq 39\end{cases}
\end{aligned}
$$

Leukopenia

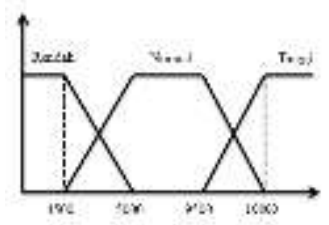

Gambar 3. kurva variabel leukopenia

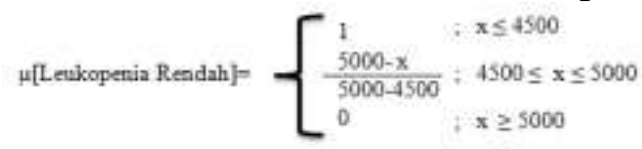

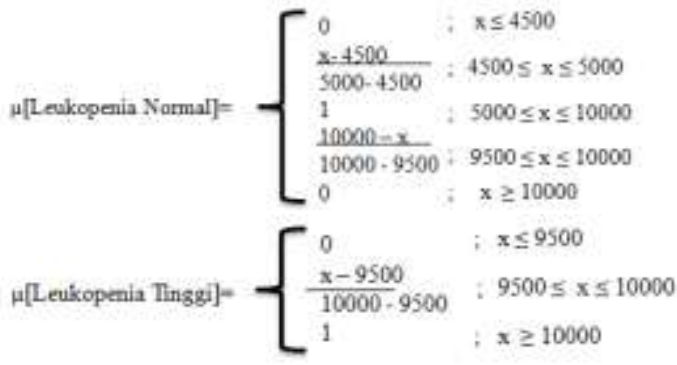

Frekuensi pernafasan

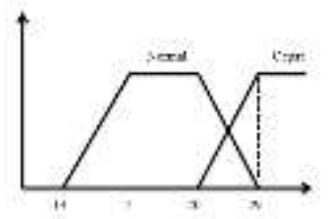

Gambar 4. kurva variabel frekuensi pernafasan

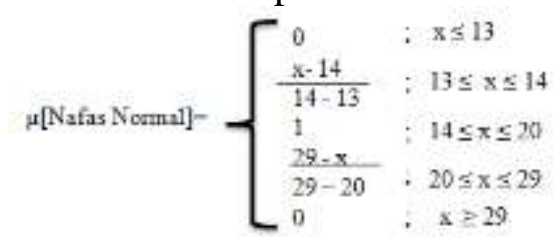

$\mu[$ Nafas Cepat $]= \begin{cases}0 & ; x \leq 20 \\ \frac{x-20}{29-20} & ; 20 \leq x \leq 29 \\ 1 & ; x \geq 29\end{cases}$

$\mathrm{PaO}_{2} / \mathrm{fiO}_{2}$

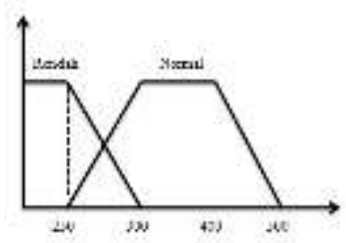

Gambar 5. kurva variabel $\mathrm{PaO}_{2} / \mathrm{fiO}_{2}$

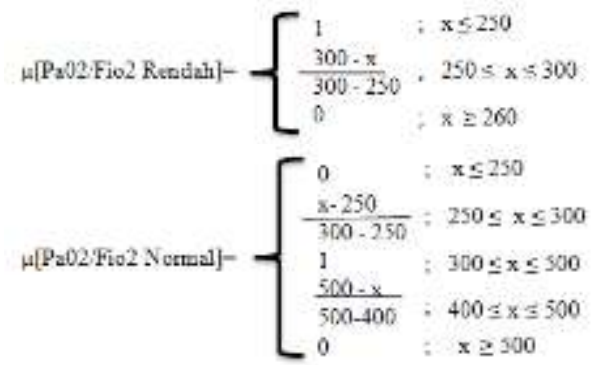

Uremia

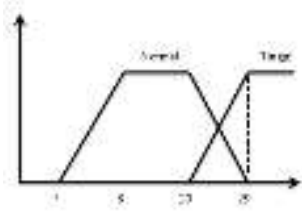

Gambar 6. kurva variabel uremia 


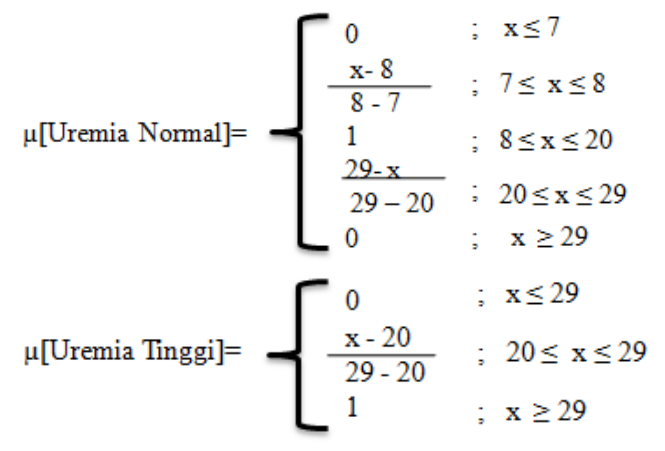

Trombosit

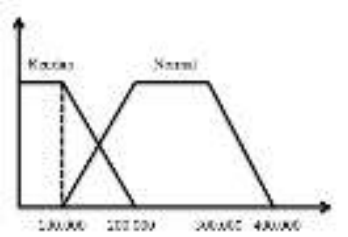

Gambar 7. kurva variabel trombosit

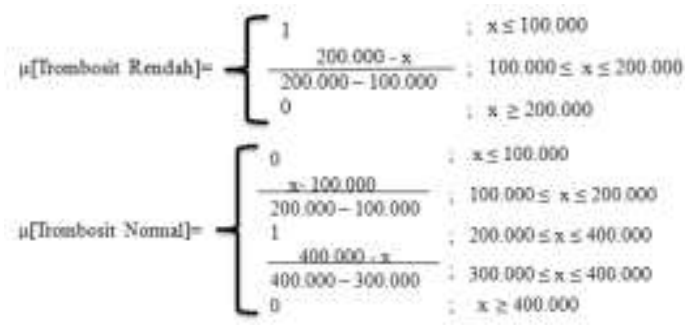

Batuk

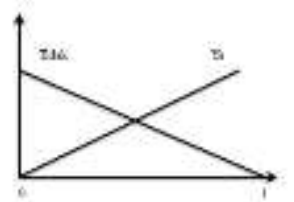

Gambar 8. kurva variabel batuk

$$
\begin{aligned}
& \mu[\text { Batuk Tidak }]= \begin{cases}1 & ; x \leq 0 \\
\frac{1-x}{1-0} ; & 0 \leq x \leq 1 \\
0 ; & x \geq 1\end{cases} \\
& \mu[\text { Batuk Ya }]= \begin{cases}0 ; & x \leq 0 \\
x-0 ; & 0 \leq x \leq 1 \\
1-0 ; & x \geq 1\end{cases}
\end{aligned}
$$

Terdapat infiltrate/air bronchogram

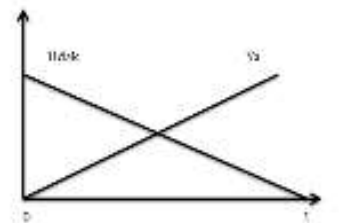

Gambar 9. kurva variabel batuk

$$
\begin{aligned}
& \mu[\text { Air Bronchogram Tidak }]= \begin{cases}1 & ; x \leq 0 \\
\frac{1-x}{1-0} & ; 0 \leq x \leq 1 \\
0 & ; x \geq 1\end{cases} \\
& \mu[\text { Air Bronchogram Ya }]= \begin{cases}0 ; & x \leq 0 \\
\frac{x-0}{1-0} ; & 0 \leq x \leq 1 \\
1 ; & x \geq 1\end{cases}
\end{aligned}
$$

Perubahan karakteristik sputum/purulen

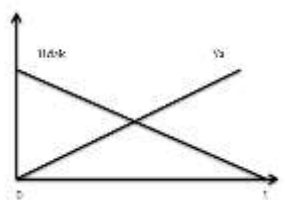

Gambar 10. kurva variabel perubahan karakteristik sputum/purulen

$$
\begin{aligned}
& \mu[\text { Sputum/Purulen Tidak }]= \begin{cases}1 & ; x \leq 0 \\
\frac{1-x}{1-0} & ; 0 \leq x \leq 1 \\
0 & ; x \geq 1\end{cases} \\
& \mu[\text { Sputum/Purulen Ya }]= \begin{cases}0, & x \leq 0 \\
\frac{x-0}{1-0} ; & 0 \leq x \leq 1 \\
1 ; & x \geq 1\end{cases}
\end{aligned}
$$

Nyeri dada

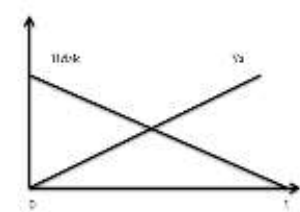

Gambar 11. variabel nyeri dada

$$
\begin{aligned}
& \mu[\text { Nyeri Dada Tidak }]= \begin{cases}1 & ; x \leq 0 \\
1-x & ; 0 \leq x \leq 1 \\
\hline 1-0 & ; x \geq 1\end{cases} \\
& \mu[\text { Nyeri Dada Ya }]= \begin{cases}0 ; & x \leq 0 \\
\frac{x-0}{1-0} ; & 0 \leq x \leq 1 \\
1 ; & x \geq 1\end{cases}
\end{aligned}
$$

Sesak

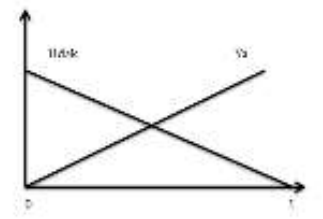


Gambar 12. variabel sesak

$$
\begin{aligned}
& \mu[\text { Sesak Tidak }]= \begin{cases}1 & ; x \leq 0 \\
1-x & ; 0 \leq x \leq 1 \\
1-0 & ; x \geq 1\end{cases} \\
& \mu[\text { Sesak Ya }]= \begin{cases}0 ; & x \leq 0 \\
\frac{x-0}{1-0} ; & 0 \leq x \leq 1 \\
1 ; & x \geq 1\end{cases}
\end{aligned}
$$

Memiliki tanda-tanda konsolidasi, suara napas bronchial dan ronki

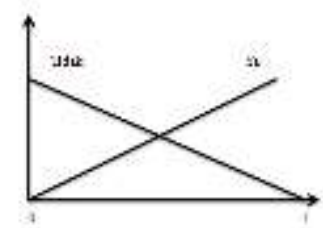

Gambar 13. veriabel memiliki tandatanda konsolidasi, suara napas bronchial dan ronki

$$
\begin{gathered}
\mu[\text { konsolidasi Tidak }]= \begin{cases}1 & ; \quad x \leq 0 \\
\frac{1-x}{1-0} & ; 0 \leq x \leq 1 \\
0 & ; x \geq 1\end{cases} \\
\mu[\text { konsolidasi Ya }]= \begin{cases}0 & ; x \leq 0 \\
\frac{x-0}{1-0} ; & 0 \leq x \leq 1 \\
1 ; & x \geq 1\end{cases}
\end{gathered}
$$

Terdapat Infiltrat Mulilobus

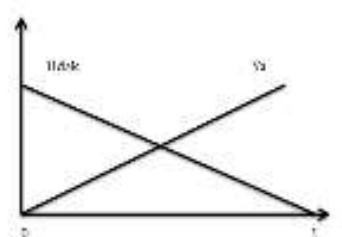

Gambar 14. variabel terdapat infiltrate mulilobus

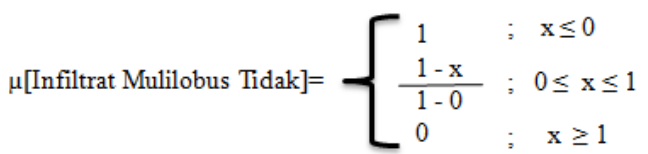

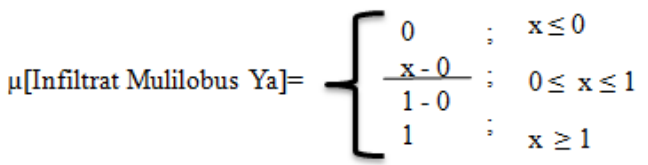

Kesadaran menurun/disorientasi

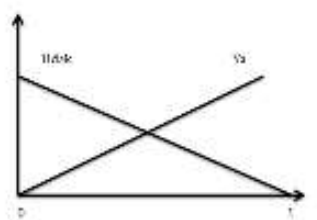

Gambar 15. variabel kesadaran menurun/disorientasi

$$
\begin{aligned}
& \mu[\text { kesadaran Tidak }]= \begin{cases}1 & ; x \leq 0 \\
\frac{1-x}{1-0} & ; 0 \leq x \leq 1 \\
0 & ; x \geq 1\end{cases}
\end{aligned}
$$

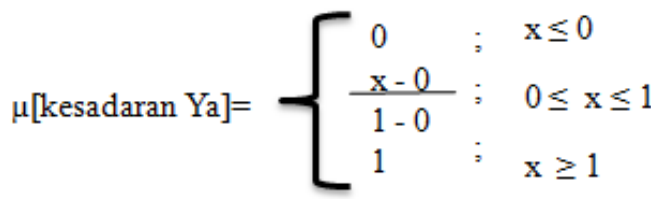

Hipotensi yang memerlukan resusitasi cairan agresif

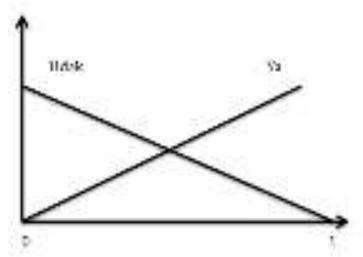

Gambar 16. variabel Hipotensi yang memerlukan resusitasi cairan agresif

$$
\begin{aligned}
& \mu[\text { hipotensi Tidak }]= \begin{cases}1 & ; x \leq 0 \\
1-x & ; 0 \leq x \leq 1 \\
1-0 & ; x \geq 1\end{cases} \\
& \mu[\text { hipotensi Ya }]= \begin{cases}0 ; & x \leq 0 \\
x-0 ; & 0 \leq x \leq 1 \\
1-0 ; & x \geq 1\end{cases}
\end{aligned}
$$

Memiliki Riwayat Penyakit Paru Lainnya

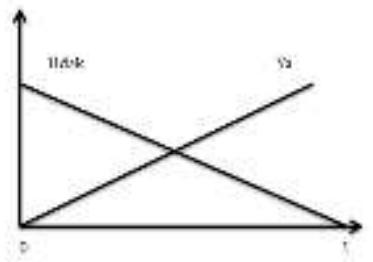

Gambar 17. Memiliki Riwayat Penyakit Paru Lainnya

$$
\mu[\text { Penyakit Paru Lain Tidak }]= \begin{cases}1 & ; x \leq 0 \\ 1-x & ; 0 \leq x \leq 1 \\ \hline 1-0 & ; x \geq 1\end{cases}
$$


$\mu[$ Penyakit Paru Lain Ya $]= \begin{cases}0 ; & x \leq 0 \\ \frac{x-0}{1-0} ; & 0 \leq x \leq 1 \\ 1 ; & x \geq 1\end{cases}$

\section{Rule}

$\mathrm{R} 1$ = IF suhu badan G1 (TINGGI) AND frekuensi pernafasan G3 (CEPAT) AND infiltrate/air bronchogram G8 AND nyeri dada G10 and sesak G11 THEN Pneumonia Rendah P1 CF=0.667

R2 = IF suhu badan G1 (TINGGI) AND Leukopenia G2 (TINGGI) AND Batuk G7 AND Terdapat infiltrate/air bronchogram G8 AND Perubahan karakteristik sputum/purulen G9 AND Memiliki tanda-tanda konsolidasi, suara napas bronchial dan ronki G12 THEN Pneumonia Rendah P1 CF=0,333

R3 = Frekuensi pernafasan G3 (CEPAT) AND $\mathrm{PaO} 2 / \mathrm{fiO} 2$ G4 (RENDAH) AND Terdapat infiltrat mulilobus G13 THEN Pneumonia Berat P2 $\mathrm{CF}=0,642$

R4 = suhu badan G1 (RENDAH) AND Leukopenia G2 (RENDAH) AND Trombosit G6 (RENDAH) AND Terdapat infiltrat mulilobus G13 AND kesadaran menurun G14 AND Hipotensi yang memerlukan resusitasi cairan agresif G15 AND Memiliki Riwayat Penyakit Paru Lainnya G16 THEN Pneumonia Berat P2 CF=0,214

R5 = suhu badan (TINGGI) G1 AND frekuensi pernafasan G3 (CEPAT) AND $\mathrm{PaO} 2$ / fiO2 G4 (RENDAH) AND uremia G5 (TINGGI) AND sesak G11 AND Terdapat infiltrat mulilobus G13 AND Memiliki Riwayat Penyakit Paru Lainnya G16 THEN Pneumonia Berat P2 $\mathrm{CF}=0,142$.

\section{Contoh kasus}

LPPM Universitas Putra Indonesia YPTK Padang
Seorang pasien memiliki gejala sebagai berikut, suhu badan $38,8^{\circ} \mathrm{C}$, leukopenia $9570 \mathrm{Sel} / \mathrm{mm}^{3}$, frekuensi pernafasan 26x/menit, $\mathrm{PaO}_{2} / \mathrm{fiO}_{2} 350 \mathrm{Mmhg}$, Uremia $15 \mathrm{Mg} / \mathrm{dl}$, Trombositopenia $250.000 \mathrm{Sel} / \mathrm{mm}^{3}$, Batuk CUKUP YAKIN, Terdapat infiltrate/air bronchogram SANGAT YAKIN, Perubahan karakteristik sputum/purulen CUKUP YAKIN, Nyeri dada YAKIN, Sesak YAKIN, Memiliki tanda-tanda konsolidasi, suara napas bronchial dan ronki TIDAK YAKIN, Memiliki Riwayat Penyakit Paru Lainnya TIDAK YAKIN.

Langkah 1 adalah fuzzyfikasi:

Suhu badan G1

$\mu($ suhu rendah $)=0$

$\mu($ suhu normal $)=0$

$\mu$ (suhu tinggi $)=1$

$=\frac{X-38}{39-38}=\frac{38,8-38}{39-38}=\frac{0,8}{1}=0,8$

Leukopenia G2

$\mu($ Leukopenia rendah $)=0$

$\mu($ Leukopenia normal $)=0$

$\mu($ Leukopenia tinggi $)=1$

$=\frac{X-9500}{10000-9500}=\frac{9570-9500}{10000-9500}=\frac{70}{500}=0,14$

frekuensi pernafasan G3

$\mu($ pernafasan normal $)=0$

$\mu($ pernafasan cepat $)=1$

$=\frac{X-20}{29-20}=\frac{26-20}{29-20}=\frac{6}{9}=0,667$

$\mathrm{PaO} 2$ / fiO2 G4

$\mu(\mathrm{PaO} 2 /$ fiO2 rendah $)=0$

$\mu(\mathrm{PaO} 2 /$ fiO2 normal $)=1$

Uremia G5

$\mu(\mathrm{PaO} 2 /$ fiO2 normal $)=1$

$\mu(\mathrm{PaO} 2 / \mathrm{fiO} 2$ tinggi $)=0$ 
Trombositopenia G6

$\mu($ Trombositopenia normal $)=1$

$\mu$ (Trombositopenia tinggi $)=0$

\section{Batuk G7}

$\mu($ Batuk tidak $)=0$

$\mu($ Batuk ya $)=1$

$1 \mathrm{x}$ nilai keyakinan user $=1 \mathrm{x}$ CUKUP

YAKIN $(0,4)=0,4$

Terdapat infiltrate/air bronchogram G8

$\mu($ air bronchogram tidak $)=0$

$\mu($ air bronchogram ya $)=1$

$1 \mathrm{x}$ nilai keyakinan user $=1 \mathrm{x}$ SANGAT

YAKIN $(1)=1$

Perubahan karakteristik sputum/purulen G9

$\mu($ sputum/purulen tidak $)=0$

$\mu($ sputum/purulen ya $)=1$

$1 \mathrm{x}$ nilai keyakinan user $=1 \mathrm{x}$ CUKUP

YAKIN $(0,4)=0,4$

Nyeri dada G10

$\mu($ Nyeri dada tidak $)=0$

$\mu($ Nyeri dada ya $)=1$

$1 \mathrm{x}$ nilai keyakinan user $=1 \mathrm{x}$

$\mathrm{YAKIN}(0,8)=0,8$

Sesak G11

$\mu($ Sesak tidak $)=0$

$\mu($ Sesak ya $)=1$

$1 \mathrm{x}$ nilai keyakinan user $=1 \mathrm{x}$

$\mathrm{YAKIN}(0,8)=0,8$

Memiliki tanda-tanda konsolidasi, suara napas bronchial dan ronki G12

$\mu($ konsolidasi tidak $)=0$

$\mu($ konsolidasi ya $)=1$

$1 \mathrm{x}$ nilai keyakinan user $=1 \mathrm{x}$ TIDAK

$\operatorname{YAKIN}(0,2)=0,2$
Terdapat infiltrat mulilobus G13

$\mu($ infiltrat mulilobus tidak $)=1$

$\mu$ (infiltrat mulilobus ya) $=0$

Kesadaran menurun/disorientasi G14

$\mu($ infiltrat mulilobus tidak $)=1$

$\mu($ infiltrat mulilobus ya $)=0$

Hipotensi yang memerlukan resusitasi cairan agresif G15

$\mu($ Hipotensi tidak $)=1$

$\mu($ Hipotensi ya $)=0$

Memiliki Riwayat Penyakit Paru Lainnya G16

$\mu($ penyakit paru lain tidak $)=0$

$\mu($ penyakit paru lain ya $)=1$

$1 \mathrm{x}$ nilai keyakinan user $=1 \mathrm{x}$ CUKUP

$\mathrm{YAKIN}(0,4)=0,4$

$\mathrm{R} 1=\mathrm{IF}$ G1 $(0,8)$ AND G3(0,667) AND

G8(1) AND G10 $(0,8)$ AND G11 $(0,8)$

THEN PNEUMONIA RENDAH CF=

0,667

$\mathrm{Z} 1=\min (0,8 ; 0,667 ; 1 ; 0,8 ; 0,8)=0,667$

$\mathrm{R} 2=\mathrm{IF}$ G1 $(0,8)$ AND G2 $(0,14)$ AND

G7 $(0,4)$ AND G8(1) AND G9 $(0,4)$ AND

G12 $(0,2)$ PNEUMONIA RENDAH CF=

0,333

$\mathrm{Z} 2=\min (0,8 ; 0,14 ; 0,4 ; 1 ; 0,4 ; 0,2)=0,14$

\section{Defuzzyfikasi}

$$
\begin{gathered}
\mathrm{z}=\frac{\sum_{i=1}^{n} W \text { izi }}{\sum_{i=1}^{n} \mathrm{Wi}} \\
=\frac{(0,667 \times 0,667)+(0,333 \times 0,14)}{0,667+0,333} \\
=\frac{0,444+0,046}{0,667+0,333} \\
=\frac{0,49}{1}=0,49
\end{gathered}
$$


Tabel 5. cf user x cf pakar

\begin{tabular}{|c|c|c|c|}
\hline Rule & Cf user & Cf pakar & $\begin{array}{c}\text { Cf user } x \\
\text { cf pakar }\end{array}$ \\
\hline R1 & 0,49 & 0,667 & 0,327 \\
\hline R2 & 0,49 & 0,333 & 0,163 \\
\hline
\end{tabular}

$\mathrm{CF}($ pneumonia rendah $)=\mathrm{CF} 1+\mathrm{CF} 2(1-$ CF1)

$=0,327+0,163(1-0,327)$

$=0,437$

Presentasi keyakinan

$=\mathrm{Cf}$ combine $\mathrm{x} 100 \%$

$=0,437 \times 100 \%$

$=43,7 \%$

Kesimpulan: pasien terdiagnosa penyakit PNEUMONIA RENDAH dengan nilai akhir sebesar $43,7 \%$

\subsection{Perancangan}

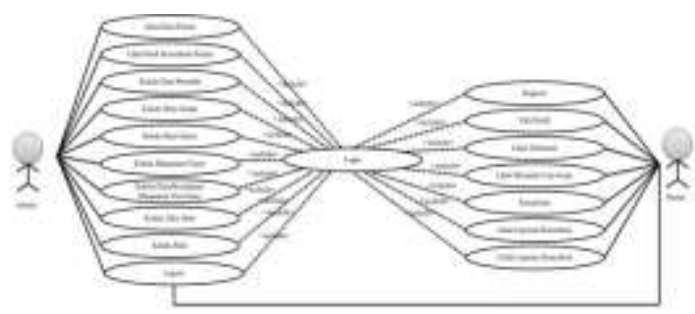

Gambar 18. Use case diagram

\subsection{Implementasi dan pengujian}
1. Tampilan Halaman Utama User(Pasien)

Halaman ini menampilkan menu - menu yang dapat diakses oleh pasien setelah pasien melakukan login.

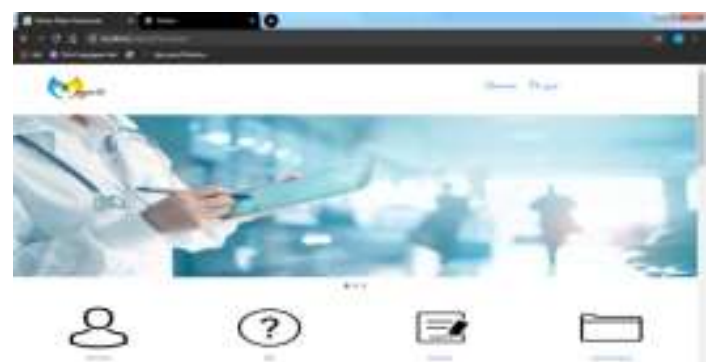

Gambar 19. Halaman beranda

2. Tampilan Halaman Konsultasi Halaman ini menampilkan pertanyaan yang diajukan kepada user(pasien), terdapat dua jenis pertanyaan pada sistem ini.

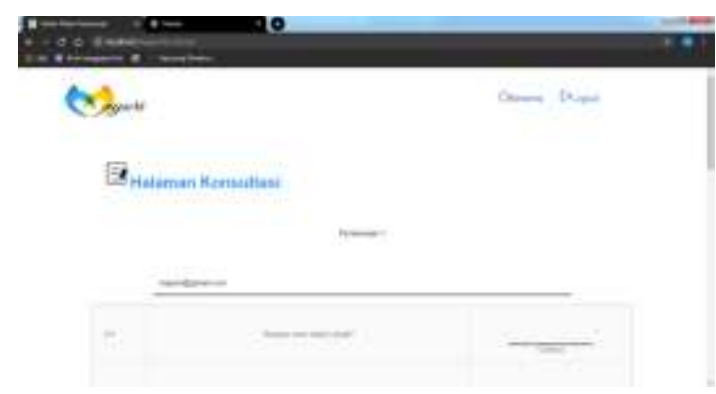

Gambar 20. halaman konsultasi user(pasien)

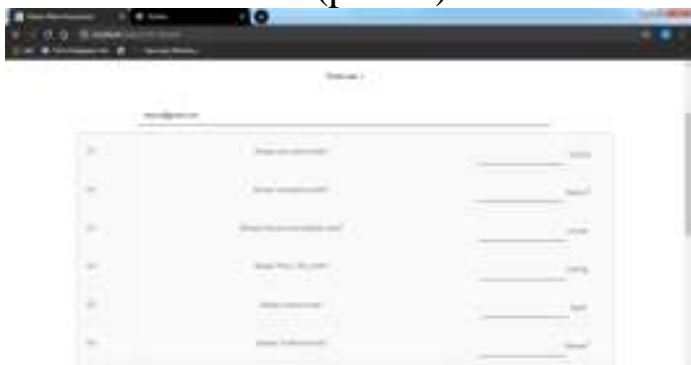

Gambar 21. halaman konsultasi user(pasien)

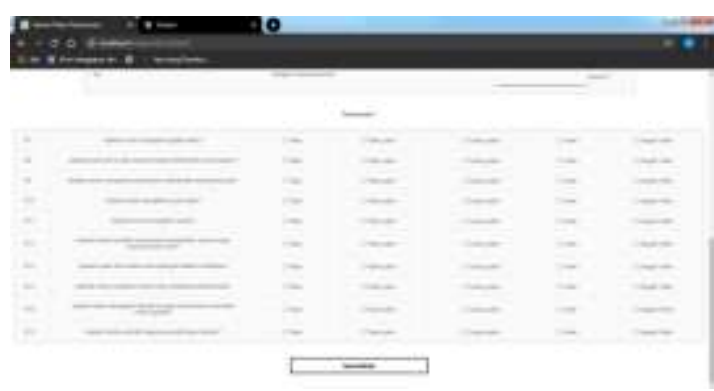

Gambar 22. halaman konsultasi user(pasien)

3. Halaman Laporan Diagnosa Halaman ini menampilkan kesimpulan dari jawaban user(pasien) setelah melakukan konsultasi, laporan tersebut dapat di cetak. 


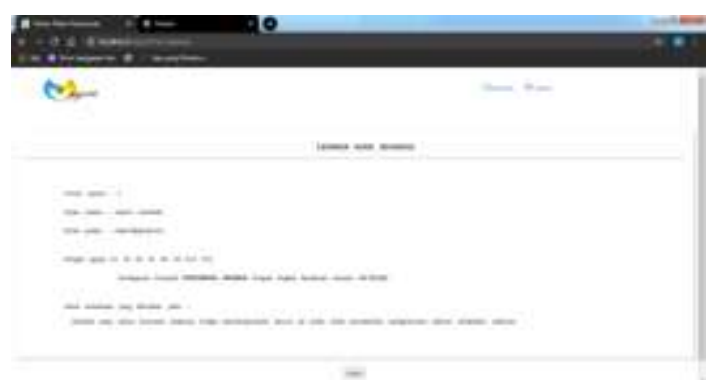

Gambar 23. halaman laporan diagnosa user(pasien)

\section{SIMPULAN}

Dari hasil analisa dan pembahasan pada skripsi sistem pakar mendiagnosa penyakit Pneumonia menggunakan metode Certainty factor dan Fuzzy logic tsukamoto ini, dapat ditarik kesimpulan sebagai bahwa :

1. Aplikasi sistem pakar mendiagnosa penyakit Pneumonia ini telah mampu memberikan informasi kepada user (pasien) mengenai penyakit Pneumonia yang dialami melalui gejala - gejala yang diinputkan user (pasien) ke sistem serta memberikan solusi atau penanganan awal sesuai dengan penyakit Pneumonia yang telah didiagnosakan.

2. Aplikasi sistem Pakar mendiagnosa penyakit Pneumonia ini telah berhasil dibangun dengan menerapkan metode Certainty Factor dan fuzzy logic tsukamoto sebagai metode perhitungan.

3. Aplikasi sistem pakar mendiagnosa penyakit Pneumonia ini memiliki data data pada program aplikasi yang dapat diubah atau diperbaharui oleh administrator jika ditemukan data baru.

\section{DAFTAR PUSTAKA}

[1] K. Jl, L. Begalung, and P. Sumatera, "Universitas Putra Indonesia " Yptk "," no. 0751, p. 776666, 2020.

[2] A. I. Falatehan, N. Hidayat, and K.
C. Brata, "Sistem Pakar Diagnosis

Penyakit Hati Menggunakan

Metode Fuzzy Tsukamoto Berbasis Android," J. Pengemb. Teknol. Inf. dan Ilmu Komput. Univ. Brawijaya, vol. 2, no. 8, pp. 2373-2381, 2018, [Online]. Available: http://jptiik.ub.ac.id/index.php/jptiik/article/view/1773.

[3] R. Moch, "identifiaksi penyakit pad tanaman pakcoy," 2019.

[4] D. I. Lesmana, "Sistem Pakar Mendiagnosa Penyakit Pneumonia Dengan Penelusuran Forward Chaining Menggunakan Metode Certainty Factor," Pelita Inform. Budi Darma, vol. 26, no. 23019425, pp. 21-24, 2017.

[5] E. Warganegara, "Pneumonia Nosokomial: Hospital-Acquired, Ventilator-Associated, dan Health Care-Associated," J. Kedokt. Unila, vol. 1, no. 3, pp. 612-618, 2017.

[6] S. Sitohang and R. Denson Napitupulu, "Fuzzy Logic Untuk Menentukan Penjualan Rumah Dengan Metode Mamdani (Studi Kasus: Pt Gracia Herald)," J. ISD, vol. 2, no. 2, 2017.

[7] A. Riadi, "Penerapan Metode Certainty Factor Untuk Sistem Pakar Diagnosa Penyakit Diabetes Melitus Pada Rsud Bumi Panua Kabupaten Pohuwato," Ilk. J. Ilm., vol. 9, no. 3, pp. 309-316, 2017, doi: 10.33096/ilkom.v9i3.162.309316.

[8] A. Sucipto, Y. Fernando, R. I. Borman, and N. Mahmuda, "Penerapan Metode Certainty Factor Pada Diagnosa Penyakit Saraf Tulang Belakang," J. Ilm. FIFO, vol. 10, no. 2, p. 18, 2019, doi: 10.22441/fifo.2018.v10i2.002.

[9] K. R. Ririh, N. Laili, A. Wicaksono, and S. Tsurayya, "Studi Komparasi dan Analisis Swot Pada Implementasi Kecerdasan Buatan 
(Artificial Intelligence) di Indonesia," J. Tek. Ind., vol. 15, no. 2, pp. 122-133, 2020, [Online]. Available:

https://ejournal.undip.ac.id/index.p hp/jgti/article/view/29183.

[10] T. S. Waruwu and S. Nasution, "Pengembangan Keamanan Web Login Portal Dosen Menggunakan Unified Modelling Languange (UML)," J. Mahajana Inf., vol. 3, no. 1, pp. 34-40, 2018.

[11] I. Akil, "Rekayasa Perangkat Lunak Dengan Model Unified Process Studi Kasus: Sistem Informasi Journal," J. Pilar Nusa Mandiri, vol. 12, no. 1, p. 11, 2016.

[12] K. Kawano, Y. Umemura, and Y. Kano, " Field Assessment and Inheritance of Cassava Resistance to Superelongation Disease 1," Crop Sci., vol. 23, no. 2, pp. 201205, 1983, doi:

10.2135/cropsci1983.0011183x00 2300020002x.

[13] E. Elisa and N. Azwanti, "Rekayasa Perangkat Lunak Untuk Jasa Pindah Berbasis Web," Rang Tek. J., vol. 2, no. 2, 2019, doi: 10.31869/rtj.v2i2.1430.

[14] Y. I. Maulana, "Perancangan Perangkat Lunak Sistem Informasi Pendataan Guru Dan Sekolah (SINDARU) Pada Dinas Pendidikan Kota Tangerang Selatan," J. Pilar Nusa Mandiri, vol. 13, no. 1, pp. 21-27, 2017.

[15] N. Novianti, D. Pribadi, and R. A. Saputra, "Sistem Pakar Diagnosa Pulmonary TB Menggunakan Metode Fuzzy Logic," J. Inform., vol. 5, no. 2, pp. 228-236, 2018, doi: 10.31311/ji.v5i2.3927.

[16] K. Karimah, Z. I. Nikmah, S. K. Aditya, and E. G. Wahyuni, "Aplikasi Web Untuk Pendeteksi Penyakit Paru-Paru Menggunakan
Metode Certainty Factor," Semin.

Nas. Inform. Medis, pp. 86-91, 2019.

[17] S. Syahnandar, R. Hidayatullah, N.

Rubiati, and R. Kurniawan,

"Implementasi Fuzzy Logic

Penentuan Kelayakan Karyawan

Mendapat Reward Ditoko Roti

Mengunakan Metode Tsukamoto," I

N F O R M a T I Ka, vol. 10, no. 2,

p. 56, 2019, doi:

10.36723/juri.v10i2.116.

[18] S. Pakar and F. Tsukamoto, "Sistem

Pakar Berbasis Logika Fuzzy

Tsukamoto Untuk Mendiagnosa

Hama Dan Penyakit Tanaman

Tebu," e-jurnal JUSITI, vol. 6, pp.

1-9, 2017, [Online]. Available:

http://garuda.ristekdikti.go.id/docu ments/detail/1076882.

[19] J. Razky, S. Rini, and Mandala Eka Praja Wijata, "Sistem Pakar

Diagnosa Penyakit Pneumonia Pada Anak Menggunakan Metode Case Based Reasoning," Sainteks, vol. 6, no. ISBN : 978-602-52720-1-1, pp. 868-872, 2019.

[20] J. Oc, "Fuzzy Logic Untuk Penyakit Kolesterol Dalam Pengambilan Golongan Obat," J. Teknol. Dan Open Source, vol. 2, no. 2, pp. 4553, 2019, doi: 10.36378/jtos.v2i2.358.

[21] A. K. Yustina Retno Wahyu Utami, Siti Rochana, "Implementasi Fuzzy Logic Dalam Sistem Pakar Untuk Mendeteksi Penyakit Kanker Serviks," J. Ilm. SINUS, vol. 15, no. 1, pp. 27-38, 2017, doi: 10.30646/sinus.v15i1.259.

[22] F. I. Mevung et al., "Diagnosis Penyakit Kejiwaan Menggunakan Metode Certainty Factor," Pros. Semin. Ilmu Komput. dan Teknol. Inf., vol. 2, no. 1, pp. 374-380, 2017.

[23] E. G. Wahyuni and A. S. Ramadhan, "Aplikasi Diagnosis 
Tingkatan Pneumonia dan Saran Pengobatan dengan Fuzzy

Tsukamoto," J. Nas. Tek. Elektro dan Teknol. Inf., vol. 8, no. 2, p. 115, 2019, doi:

10.22146/jnteti.v8i2.500.

[24] Y. Ferdiansyah and N. Hidayat, "Implementasi Metode Fuzzy Tsukamoto Untuk Diagnosis Penyakit Pada Kelamin Laki Laki," J. Pengemb. Teknol. Inf. dan Ilmu Komput., vol. 2, no. 12, pp. 7516-7520, 2018. 